\title{
Efficient Adsorptive of Carbofuran Via Tailored Porous Polyacrylonitrile Film Incorporated Ti-MIL Coordination Polymer
}

\author{
Munirah D. Albaqami \\ King Saud University \\ Amal O. Alobaid \\ King Saud University \\ Ayman nafady ( $\sim$ anafady@ksu.edu.sa ) \\ King Saud University https://orcid.org/0000-0003-1484-6894
}

\section{Research Article}

Keywords: Polyacrylonitrile, NH2-MIL-Ti@P-PAN, Carbofuran, Adsorptive removal, Reusability

Posted Date: October 18th, 2021

DOI: https://doi.org/10.21203/rs.3.rs-978002/v1

License: (c) (i) This work is licensed under a Creative Commons Attribution 4.0 International License.

Read Full License 


\section{Abstract}

Carbofuran is largely applied insecticide which resulted in its wide spreading in ground/surface water and food products and consequently investigation of efficient techniques for removal of carbofuran is extensively considered. Herein, facile approach for removal of carbofuran was developed via exploitation of highly adsorptive porous film based on polyacrylonitrile (PAN) and $\mathrm{NH}_{2}-\mathrm{MIL}-\mathrm{Ti}$ as a coordination polymer. $\mathrm{NH}_{2}-\mathrm{MIL}-\mathrm{Ti} @ P-P A N$ film was prepared by immobilization of $\mathrm{NH}_{2}-\mathrm{MIL}$-Ti within the pre-prepared porous (P-PAN) film. The pore diameter of PAN film was estimated to be $8.5-51.2 \mu \mathrm{m}$. The removal of carbofuran from the porous film was systematically studied and fitted to both pseudo $2^{\text {nd }}$ ordered and Langmuir models. Results showed that Langmuir maximum removal of carbofuran was largely enhanced from 292.2 mg/g for P-PAN to 489.5 - 690.1 mg/g for $\mathrm{NH}_{2}$-MIL-Ti@P-PAN. Thus, by increasing the amount of immobilized $\mathrm{NH}_{2}$-MIL-Ti@P-PAN in the film, the adsorption capacity of carbofuran was markedly improved, reaching a 2.4 times higher when $30 \% \mathrm{NH}_{2}-\mathrm{MIL}-\mathrm{Ti}$ is immobilized. Importantly, after six reusing times, the removal of carbofuran by $30 \% \mathrm{NH}_{2}$-MIL-Ti@P-PAN film was decreased by only $12.5 \%$. The overall results attest that the fabricated $\mathrm{NH}_{2}$-MIL-Ti@P-PAN film could be efficiently used for trace removal of various insecticides and other environmental applications.

\section{Introduction}

Nowadays, carbamates are the most widely applicable type of insecticides attributing to that, among the alternative insecticides, organochlorines are disadvantageous with long-lasting residues persisting, and organophosphates (OPs) are known to be highly toxic leading to delay the neurotoxicity problems. Carbofuran (Furadan) as one of carbamates is large scaled-exploitable in forestry and agriculture as a wide-spectrum systemic acaricide, nematicide, and insecticide. Therefore, its application resulted in its wide spreading in atmospheric air, food products, groundwater and surface water are polluted with carbofuran and its metabolic products [1-4], which might affect the health of life-being. Carbofuran is a white, crystalline solid compound with a melting point of $150-152^{\circ} \mathrm{C}$, water solubility of $700 \mathrm{ppm}$ at $25^{\circ} \mathrm{C}$, vapor pressure $2 \times 10 \sim 5 \mathrm{~m} \mathrm{Hg}$ at $33^{\circ} \mathrm{C}$, and specific gravity 1.18 at $20^{\circ} \mathrm{C} / 20^{\circ} \mathrm{C}$. Carbofuran is chemically identified as 2,2-dimethyl-7-coumaranyl-N-methylcarbamate, or 2,2-dimethyl-2,3-dihydro- 7-benzofuranyl$\mathrm{N}$-methylcarbamate, or methyl carbamic acid 2,3-dihydro 2,2-dimethyl-7-benzofuranyl ester, or2,3-dihydro2,2-dimethyl-7-benzofuranol methylcarbamate. Additionally, carbofuran chemical formula is known as $\mathrm{C}_{12} \mathrm{H}_{15} \mathrm{NO}_{3}$, while, its molecular weight is 221.26 . Carbofuran exhibited high toxic effects to human beings via the oral administration and inhalation route, that subsequently resulted in pose a dangerous threating to people who are immediately in contact with it (in industrialization, plants formulation and in cropping).

Adsorptive removal of various types of insecticides from the surrounding environmental media is the most applicable technique[5] 
. Referring to numerous approaches that were considered with investigating of different adsorbing reagents like, monetite, quartz, calcite, kaolinite, gold nanoparticles [6]

, alumina, wheat straw, mesoporous carbon, graphene-based materials

[7]and activated carbon that were exploited as adsorptive removing reagent for insecticides [8-18]

. The poor application of such reported adsorbing reagents could be attributed to their solidified form and high costing (such as gold nanoparticles). Many other adsorbing reagents including nanocellulose [19], poly-vinyl-amine/nanocellulose composite [20] and hydrocalumite-iron oxide/dodecyl sulfate composite [21] are used for removing of different types of insecticides.

On the other hand, for removal of carbofuran, several adsorbents were reported in literature such as indian soils, sugarcane bagasse bio-char, animal bone meal, tea waste bio-chars, magnetic peanut shell, activated carbon, date seed activated carbon, modified maize cobs waste, steam-activated biochar, palm oil fronds activated carbon, magnetic sugarcane bagasse, mesoporous activated carbon, steel industry wastes, activated carbon from rice straw and rice straw-derived activated carbon [22-28]. All of these applicable adsorbents were exhibited quite low adsorption capacity ranged in $(0.9-312.5 \mathrm{mg} / \mathrm{g})$, in addition to, their existence in powder form, resulted in difficulty for their commercial application. Whereas, the adsorption capacity was very low, resulting in making the investigation of highly adsorbent/costless materials is extensively considered.

Recently, different coordination polymeric structures (CPs) were widely applicable in adsorptive removing of insecticides, such like Al-CP, Zr-CP, Zn-CP and Cu-CP [29-34]. Liu et al., investigated that, cyclodextrin/garphene oxide/FeO/Cu-CP composite can be applied in adsorptive removing of neonicotinoid with adsorption capacity of $1.8-3.1 \mathrm{mg} / \mathrm{g}$ [29]. More superior adsorptive action for carbon nano-tubes@Zn-CP composite, Zn-CP and quaternary amine treated Zn-CP as identified for removing of prothiofos, ethione \& phosphate, respectively [30-32]. In accordance to our knowledge, no research approaches were interested in adsorptive removal of cabrofuran using coordination polymers including film [35]

Using of reusable films for insecticides removal was advantageous with higher recoverability. Hence, the importance of the present approach is designing of a highly applicable Ti-CP@porous polyacrylonitrile ( $\mathrm{NH}_{2}$-MIL-Ti@P-PAN) film for efficient removal of carbofuran insecticide. The prepared film was examined by scanning electron microscope, X-ray diffraction and infra-red spectroscopy. The removal of carbofuran onto the synthesized film was investigated. The adsorption kinetic, isotherm and recyclability of carbofuran were all examined.

\section{Experimental}

\section{Chemicals and materials}


Titanium iso-propoxide $\left(\mathrm{TiC}_{12} \mathrm{H}_{28} \mathrm{O}_{5}, 99 \%\right)$, 2-aminoterephthalic acid $\left(\mathrm{C}_{8} \mathrm{H}_{7} \mathrm{NO}_{4}, 99 \%\right), \mathrm{N}, \mathrm{N}$ dimethylformamide (DMF, $\left.\mathrm{C}_{3} \mathrm{H}_{7} \mathrm{NO}, 99.9 \%\right)$, ethanol $\left(\mathrm{C}_{2} \mathrm{H}_{6} \mathrm{O}, 99.9 \%\right)$, methanol $\left(\mathrm{CH}_{4} \mathrm{O}, 99.9 \%\right)$, benzoic acid $\left(\mathrm{C}_{7} \mathrm{H}_{6} \mathrm{O}_{2}, 99.5 \%\right)$ and Carbofuran $\left(\mathrm{C}_{12} \mathrm{H}_{15} \mathrm{NO}_{3}\right.$, analytical standard) were all purchased from SigmaAldrich and used without purification. Acrylic fabric wastes as source for polyacrylonitrile were purchased from Misr El-Mahalla for Spinning and Weaving, Egypt.

\section{Process}

Polyacrylonitrile film (PAN) was synthesized from acrylic fabric wastes as follows: $10 \mathrm{~g}$ of acrylic fabric wastes was dissolved in $100 \mathrm{~mL} \mathrm{DMF}$ at $60^{\circ} \mathrm{C}$ for 2 hours. The colloid was added and casted on glass slide via a membrane applicator. The film was formed by impregnation in distillated $\mathrm{H}_{2} \mathrm{O}$ as coagulating bath of for 1 hour at room temperature. The obtained PAN film was taken out and dried at ambient conditions prior to be used.

Porous polyacrylonitrile (P-PAN) film was obtained in two step processes. Acrylic fabric wastes $(10 \mathrm{~g})$ were solubilized in dimethyl formamide $(100 \mathrm{~mL})$ at $60^{\circ} \mathrm{C}$ for 2 hours, then $0.5 \mathrm{~g}$ of benzoic acid was added. The colloid was stirred for $2 \mathrm{~h}$ at $60^{\circ} \mathrm{C}$ to be casted by membrane applicator. The film was completely formed by doping in the coagulation water bath. The immobilized benzoic acid was eliminated from the obtained film by formation of water soluble sodium benzoate form through doping in $100 \mathrm{~mL}$ of $5 \mathrm{~N}$ sodium hydroxide for 1 hour. The P-PAN film was taken out, washed with distilled $\mathrm{H}_{2} \mathrm{O}$ and then dried at ambient conditions.

Titanium-based coordination polymer $\left(\mathrm{NH}_{2}-\mathrm{MIL}-\mathrm{Ti}\right)$ was individually synthesized and then immobilized within the synthesized P-PAN film with two different weights (10\% \& $30 \%)$. $\mathrm{NH}_{2}$-MIL-Ti was prepared according to the previously reported method in literature [36]. The freshly synthesized $\mathrm{NH}_{2}-\mathrm{MIL}-\mathrm{Ti}$ was firstly dispersed in $50 \mathrm{~mL}$ ethanol and then P-PAN film was immersed under stirring for half hour. The resulted $\mathrm{NH}_{2}$-MIL-Ti@P-PAN film was removed for rinsing with distilled $\mathrm{H}_{2} \mathrm{O}$ and consequent drying prior to analysis and application.

\section{Instrumental analyses and characterization}

The immobilized Ti \& $\mathrm{NH}_{2}-\mathrm{MIL}-\mathrm{Ti} \mathrm{CP}$ in the film were detected from weight difference before and after the elimination of $\mathrm{NH}_{2}-\mathrm{MIL}-\mathrm{Ti}$. CP was removed from film by dissolving in ammonia in accordance to the previously reported methodology [37]. Taking in account the chemical construction of $\mathrm{NH}_{2}-\mathrm{MIL}-\mathrm{Ti}, \mathrm{Ti}$ contents were calculated by normalization to the $\mathrm{NH}_{2}-\mathrm{MIL}-\mathrm{Ti}$ contents.

The morphological features of P-PAN and $\mathrm{NH}_{2}$-MIL-Ti@P-PAN films were shown by HR Quanta FEG 250 scanning electron microscopy with field emission gun. Analyses were performed using energy dispersive X-ray detector attached to microscope. Diffractograms were detected using Malvern PANalytical

$X^{\prime}$ PertPRO diffractometer $(\lambda=1.5406 \AA)$. Diffraction angles were estimated at $3.5^{\circ}-80^{\circ}$. Spectral results 
of Fourier Transformation Infrared (FTIR) for the prepared films were measured via FT/IR $6100 \mathrm{JASCO}$ spectrometer. The results was detected with absorption mode in the spectral range of $4000-400 \mathrm{~cm}^{-1}$.

\section{Removal of Carbofuran}

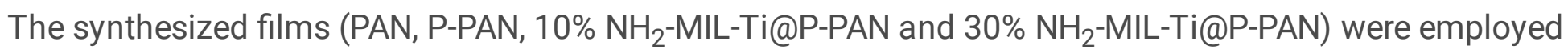
in removal of carbofuran insecticide. The adsorption isotherms were estimated at $30^{\circ} \mathrm{C}$ and the kinetics parameters were followed up to 150 minutes. Carbofuran adsorption was carried out by adding $75 \mathrm{mg}$ of film within $100 \mathrm{~mL}$ of carbofuran (50 - $2000 \mathrm{ppm}$ ). After removal, carbofuran residues was estimated via JASCO UV 630spectrophotometer. Each adsorption experiment was determined for 2 times and average value was only considered. The recyclability of the films in carbofuran adsorption was considered via reusing of the prepared films. After the first application, the used films was removed and the adsorbed carbofuran particles were leached out from film surface by dissolution in acetonitrile. Films were then dried at ambient conditions to be re-applied in the subsequent cycle. The recovered films were used in the higher cycle of carbofuran adsorption and the re-application was carried out for 4 repetitive cycles.

\section{Results And Discussion}

Characterization of the synthesized films

Porous P-PAN film was firstly synthesized to perform as the porous structure with highly efficient adsorption sites. The immobilized benzoic acid was removed by sodium hydroxide forming porous structure PAN film. The film of $\mathrm{NH}_{2}-\mathrm{MIL}-\mathrm{Ti} @ P-P A N$ was obtained with $10 \%$ and $30 \% \mathrm{CP}$ contents. The mechanism of $\mathrm{NH}_{2}-\mathrm{MIL}-\mathrm{Ti} @ \mathrm{P}-\mathrm{PAN}$ synthesis could be hypothesized as suggested in Figure 1. The nitrile groups of PAN molecules can by chemically interacted with the Ti-CP through several interactions. The nitrogen atom of nitrile groups in PAN may form coordination and hydrogen bonds with the titanium atom and hydrogen of amino groups in the Ti-CP, respectively [38]. Moreover, $\pi-\pi$ interactions can take a place between the groups of nitrile in PAN and aromatic nucleus of 2-aminoterephethalic acid in Ti-CP.

The content of Ti-CP within the P-PAN films were estimated and recorded in Table 1. The evaluated contents of Ti-CP were $106.5 \mathrm{mg} / \mathrm{g}$ for $10 \% \mathrm{NH}_{2}$-MIL-Ti@P-PAN film and $288.2 \mathrm{mg} / \mathrm{g}$ for $30 \% \mathrm{NH}_{2}-\mathrm{MIL}-$ Ti@P-PAN film. The real contents (10.65\% and 28.85\%) of Ti-CP are quite close to that theoretically added. The amounts of Ti metal in the films were evaluated by using the chemical structure of $\mathrm{NH}_{2}-\mathrm{MIL}-$ Ti. $\mathrm{Ti}_{8} \mathrm{C}_{48} \mathrm{H}_{34} \mathrm{O}_{36} \mathrm{~N}_{6}$ is the chemical formula for $\mathrm{NH}_{2}-\mathrm{MIL}-\mathrm{Ti}$ and consequently, the percentage of $\mathrm{Ti}$ in the $\mathrm{Ti}-\mathrm{CP}$ is $23.2 \%$. Based on such calculations, the Ti contents were calculated to be 24.7 and $66.9 \mathrm{mg} / \mathrm{g}$ in case of 10\% $\mathrm{NH}_{2}-\mathrm{MIL}-\mathrm{Ti} @ P-P A N$ and 30\% $\mathrm{NH}_{2}$-MIL-Ti@P-PAN films, respectively. 
Table 1

Material contents for the obtained films.

\begin{tabular}{|lll|}
\hline Film & $\begin{array}{l}\text { Ti-CP } \\
(\mathrm{mg} / \mathrm{g})\end{array}$ & $\begin{array}{l}\mathrm{Ti} \\
(\mathrm{mg} / \mathrm{g})\end{array}$ \\
\hline P-PAN & 0.0 & 0.0 \\
\hline 10\% $\mathrm{NH}_{2}$-MIL-Ti@P-PAN & 106.5 & 24.7 \\
\hline 30\% $\mathrm{NH}_{2}$-MIL-Ti@P-PAN & 288.2 & 66.9 \\
\hline
\end{tabular}

The synthesized films (P-PAN, 10\% $\mathrm{NH}_{2}$-MIL-Ti@P-PAN and 30\% $\mathrm{NH}_{2}$-MIL-Ti@P-PAN) were examined under the electronic microscope. Figure 2 showed that highly porous structure was observed for PAN after removing of organic acid. The surface of P-PAN film is beehive like shaped. The diameter of the seen pores was measured and was ranged in $8.5-51.2 \mu \mathrm{m}$ which confirmed the macro porous structure of the produced film. The pore diameter can be divided to two regions of $8.5-22.6 \mu \mathrm{m}$ and $31.8-51.2 \mu \mathrm{m}$. For $\mathrm{NH}_{2}$-MIL-Ti@P-PAN film, crystalline Ti-CP were densely distributed over the surface of the P-PAN film and filled the small pores. Crystalline disc structure of $\mathrm{NH}_{2}-\mathrm{MIL}$-Ti was seen onto the P-PAN film surface with size dimensions of $84.0-98.0 \times 167.9-654.1 \mathrm{~nm}$. The amount of $\mathrm{NH}_{2}-\mathrm{MIL}$-Ti onto the surface of P-PAN film was increased by increment of the impregnated ratio from $10-30 \%$. The EDX analysis showed the signals of $\mathrm{C}$ and $\mathrm{N}$ for P-PAN film. While, the signals of $\mathrm{O}$ and Ti were both recorded besides those of $\mathrm{C} \& \mathrm{~N}$ in case of $\mathrm{NH}_{2}-\mathrm{MIL}-\mathrm{Ti} @ P$-PAN film which further confirmed the incorporation of Ti-CP within the film.

The XRD for the as-synthesized films were shown in Figure 3 for more confirmation to the successive preparation of the as-required films. For P-PAN film, two diffractions at $2 \theta^{\circ}=17.2^{\circ}$ (strong) and $29.3^{\circ}$ (weak) characterized for (100) and (110) crystalline indices of PAN [39, 40]. $\mathrm{NH}_{2}$-MIL-Ti powder showed many characterized diffractions at $2 \theta^{\circ}=6.6^{\circ}, 9.8^{\circ}$ and $11.7^{\circ}, 15.3^{\circ}, 16.7^{\circ}, 18.0^{\circ}, 19.6^{\circ} 21.6^{\circ}, 22.7^{\circ}$ and $25.4^{\circ}$ which were strongly matched with the diffractions in literature $[41,42]$. For $\mathrm{NH}_{2}$-MIL-Ti@P-PAN films, the diffraction patterns of $\mathrm{NH}_{2}-\mathrm{MIL}-\mathrm{Ti}$ were observably obtained beside those of PAN which further confirming the successive immobilized of $\mathrm{NH}_{2}-\mathrm{MIL}-\mathrm{Ti}$ in the P-PAN film. The intensity of $\mathrm{NH}_{2}-\mathrm{MIL}-\mathrm{Ti}$ diffraction was higher in case of impregnation higher Ti-CP contents.

The chemical interaction between P-PAN and $\mathrm{NH}_{2}-\mathrm{MIL}-\mathrm{Ti}$ in the as-synthesized films was illustrated via FTIR spectra (Figure 4a). From the plotted spectra, it could be depicted that, P-PAN film was shown with three main absorption peaks at 2918-2844 cm $\mathrm{cm}^{-1}, 2240 / 1728 / 1659 \mathrm{~cm}^{-1}$ and $1443-1226 \mathrm{~cm}^{-1}$. The detected peaks are attributed to the aliphatic $\mathrm{C}-\mathrm{H}$, the nitrile group and $\mathrm{CH}_{2} \& \mathrm{CH}_{3}$ groups which referring to the chemical structural of PAN $[43,44]$. For $\mathrm{NH}_{2}-\mathrm{MIL}$-Ti powder, four prime peaks were recorded for $\mathrm{NH}$ group at $3427 \mathrm{~cm}^{-1}, \mathrm{OH}$ groups at $3318 \mathrm{~cm}^{-1}$, carboxylate group of 2-aminoterephthalic acid at $1659 / 1537 \mathrm{~cm}^{-1}$ and Ti-O bond at $752 \mathrm{~cm}^{-1}[45,46]$. In case of $\mathrm{NH}_{2}-\mathrm{MIL}-\mathrm{Ti} @ P-P A N$ film, the 
characterized absorption peaks of $\mathrm{NH}_{2}-\mathrm{MIL}-\mathrm{Ti}$ were significantly observed beside that of PAN. The intensities of the absorption peaks for $\mathrm{NH}_{2}-\mathrm{MIL}-\mathrm{Ti}$ became stronger at impregnation higher Ti-CP content in the film. These spectral mapping data are further support the data of XRD diffraction and microscopic observations.

\section{Removal of carbofuran}

The so-prepared films (PAN, P-PAN, 10\% NH $\mathrm{NH}_{2}$ MIL-Ti@P-PAN, 30\% $\mathrm{NH}_{2}$-MIL-Ti@P-PAN) were employed in the adsorptive removing of carbofuran insecticide. Firstly, FTIR spectral mapping data (Figure 4b) were illustrated for approval of the adsorption processing using the prepared films. After adsorption of carbofuran onto the $\mathrm{NH}_{2}$-MIL-Ti@P-PAN film, three new base absorption peaks were observed at 3356 $\mathrm{cm}^{-1}, 2972 \mathrm{~cm}^{-1}, 1519 \mathrm{~cm}^{-1}$ and $868 \mathrm{~cm}^{-1}$. These peaks are characterized for $\mathrm{NH}, \mathrm{CH}$ aliphatic, $\mathrm{C}=\mathrm{C}$ of aromatic and $\mathrm{CH}$ aromatic for the carbofuran molecule $[26,28]$. Moreover, the amide- $\mathrm{C}=\mathrm{O}$ was overlapped with that for $\mathrm{CN}$ of PAN. These interoperations affirmed the adsorption of carbofuran onto the as-applied $\mathrm{NH}_{2}$-MIL-Ti@P-PAN film.

The adsorptive removal of carbofuran was systematically monitored via the investigation of the characteristic absorption peak at $290 \mathrm{~nm}$. Adsorption capacities of the carbofuran were detected with time and plotted in Figure 5. The plotted data showed that, adsorption of carbofuran using the synthesized films was enhanced by prolonging the duration and the adsorption was fast in the first adsorption hour, to be subsequently slowed down with prolonged duration. The adsorption capacities of carbofuran onto the applied films were followed the order of PAN $<$ P-PAN $<10 \% \mathrm{NH}_{2}-\mathrm{MIL}-\mathrm{Ti} @ P-P A N<<$ $30 \% \mathrm{NH}_{2}$-MIL-Ti@P-PAN. Whereas, within only 2.5 hours, almost all carbofuran were removed by using $30 \% \mathrm{NH}_{2}$-MIL-Ti@P-PAN film. In the first hour, the removal amounts of carbofuran were 86.6, 126.6, 180.0 and $300.0 \mathrm{mg} / \mathrm{g}$ when PAN, P-PAN, 10\% $\mathrm{NH}_{2}$-MIL-Ti@P-PAN and 30\% $\mathrm{NH}_{2}$-MIL-Ti@P-PAN films were applied, respectively. The removal amounts of carbofuran onto the corresponding film were increased up to $110.0,153.3,220.0$ and $360.0 \mathrm{mg} / \mathrm{g}$, respectively after 2.5 hours of contact time. The lowest removal capacity was recorded for PAN due to the limited interaction with carbofuran and absence of porous structure. While, the removal was slightly improved by formation of porous film of P-PAN. The adsorption of carbofuran onto the exploitable P-PAN film was progressively increased by immobilization of $\mathrm{NH}_{2}-\mathrm{MIL}$ Ti. Removal was observably enhanced by increment the impregnated $\mathrm{NH}_{2}-\mathrm{MIL}-\mathrm{Ti}$, owing to increasing of the reactive adsorptive sites.

Eventually, the kinetic parameters for adsorption removal of carbofuran onto the synthesized films were carried out for nonlinear model of pseudo-1 st ordered and pseudo-2nd ordered (Figure 5). For examination the fitting of adsorption data, the value of correlation coefficient $\left(R^{2}\right)$ and Chi-squared test $\left(x^{2}\right)$ were measured and all parameters were tabulated in Table 2. Attributing to higher values of $\mathrm{R}^{2}$ and smaller values of $x^{2}$, the adsorption of carbofuran onto the films was well described by pseudo-2nd ordered modelling which means that the removal of carbofuran depended on the concentration of carbofuran and amount of applied film. Additionally, attributing to the observable increasing of 
adsorption sites, the rate constant $\left(\mathrm{k}_{2}\right)$ was considerably reduced from $2.9 \times 10^{-4} \mathrm{~L} / \mathrm{mg}$.min for P-PAN film to $1.3 \times 10^{-4} \mathrm{~L} / \mathrm{mg}$.min for $30 \% \mathrm{NH}_{2}-\mathrm{MIL}-\mathrm{Ti} @ P$-PAN film. This observation could mean that the rate of carbofuran removal using the synthesized films was accelerated by $55 \%$ when $30 \%$ of $\mathrm{NH}_{2}-\mathrm{MIL}-\mathrm{Ti}$ immobilized within the P-PAN film. 
Table 2

Adosprtion parameters of adsorption kietics and isotherm for carbofruan onto the synthesized films.

\begin{tabular}{|c|c|c|c|c|c|}
\hline Model & Parameter & PAN & P-PAN & $\begin{array}{l}10 \% \mathrm{NH}_{2}-\mathrm{MIL}- \\
\text { Ti@P-PAN }\end{array}$ & $\begin{array}{l}30 \% \mathrm{NH}_{2}-\mathrm{MIL}- \\
\text { Ti@P-PAN }\end{array}$ \\
\hline & $\begin{array}{l}Q_{e} \text { exp. } \\
(\mathrm{mg} / \mathrm{g})\end{array}$ & 110.0 & 153.3 & 220.0 & 360.0 \\
\hline \multirow[t]{5}{*}{$\begin{array}{l}\text { Pseudo-first } \\
\text { order }\end{array}$} & $\mathrm{Q}_{\mathrm{e}}(\mathrm{mg} / \mathrm{g})$ & $\begin{array}{l}105.3 \pm \\
1.9\end{array}$ & $\begin{array}{l}148.8 \pm \\
1.8\end{array}$ & $211.4 \pm 3.1$ & $347.4 \pm 6.9$ \\
\hline & $\mathrm{K}_{1} \times 10^{-3}$ & $\begin{array}{l}32.4 \pm \\
2.3\end{array}$ & $\begin{array}{l}35.6 \pm \\
1.7\end{array}$ & $36.1 \pm 2.2$ & $40.9 \pm 3.6$ \\
\hline & $\left(\min ^{-1}\right)$ & & & & \\
\hline & $\mathrm{R}^{2}$ & 0.98 & 0.99 & 0.99 & 0.98 \\
\hline & $\chi^{2}$ & 12.6 & 11.6 & 37.4 & 213.7 \\
\hline \multirow[t]{5}{*}{$\begin{array}{l}\text { Pseudo-second } \\
\text { order }\end{array}$} & $\mathrm{Q}_{\mathrm{e}}(\mathrm{mg} / \mathrm{g})$ & $\begin{array}{l}127.1 \pm \\
1.4\end{array}$ & $\begin{array}{l}177.3 \pm \\
1.1\end{array}$ & $250.8 \pm 1.6$ & $403.4 \pm 4.9$ \\
\hline & $\mathrm{K}_{2} \times 10^{-4}$ & $\begin{array}{l}2.9 \pm \\
0.2\end{array}$ & $\begin{array}{l}2.4 \pm \\
0.1\end{array}$ & $1.7 \pm 0.1$ & $1.3 \pm 0.1$ \\
\hline & (L/mg.min) & & & & \\
\hline & $\mathrm{R}^{2}$ & 0.99 & 0.99 & 0.99 & 0.99 \\
\hline & $x^{2}$ & 1.5 & 1.1 & 2.6 & 29.2 \\
\hline \multirow[t]{4}{*}{$\begin{array}{l}\text { Freundlich } \\
\text { isotherm }\end{array}$} & $\mathrm{n}$ & $\begin{array}{l}2.9 \pm \\
0.5\end{array}$ & $\begin{array}{l}2.5 \pm \\
0.2\end{array}$ & $2.2 \pm 0.1$ & $2.7 \pm 0.3$ \\
\hline & $\mathrm{K}_{\mathrm{F}}$ & $\begin{array}{l}12.5 \pm \\
2.2\end{array}$ & $\begin{array}{l}12.8 \pm \\
2.9\end{array}$ & $15.5 \pm 2.8$ & $45.2 \pm 5.4$ \\
\hline & $\mathrm{R}^{2}$ & 0.92 & 0.97 & 0.98 & 0.96 \\
\hline & $x^{2}$ & 223.5 & 225.1 & 326.2 & 2005.9 \\
\hline \multirow[t]{5}{*}{$\begin{array}{l}\text { Langmuir } \\
\text { isotherm }\end{array}$} & $\mathrm{Q}_{\max }$ & $\begin{array}{l}160.8 \pm \\
4.2\end{array}$ & $\begin{array}{l}292.2 \pm \\
5.8\end{array}$ & $489.5 \pm 13.3$ & $690.1 \pm 13.1$ \\
\hline & $\left(\mathrm{mg} \mathrm{g}^{-1}\right)$ & & & & \\
\hline & $\mathrm{K}_{\mathrm{L}} \times 10^{-3}$ & $\begin{array}{l}4.7 \pm \\
0.4\end{array}$ & $\begin{array}{l}3.0 \pm \\
0.2\end{array}$ & $2.6 \pm 0.2$ & $5.1 \pm 0.3$ \\
\hline & $(\mathrm{mg} / \mathrm{L})$ & & & & \\
\hline & $\mathrm{R}^{2}$ & 0.99 & 0.99 & 0.99 & 0.99 \\
\hline
\end{tabular}




\begin{tabular}{|llllll|}
\hline Model & Parameter & PAN & P-PAN & $\begin{array}{l}10 \% \mathrm{NH}_{2}-\mathrm{MIL}- \\
\text { Ti@P-PAN }\end{array}$ & $\begin{array}{l}\text { 30\% } \mathrm{NH}_{2} \text {-MIL- } \\
\text { Ti@P-PAN }\end{array}$ \\
\hline$\chi^{2}$ & 19.7 & 21.6 & 82.5 & 157.6 \\
\hline
\end{tabular}

The nonlinear isotherm fitting for carbofuran adsorption onto the as-synthesized films was investigated in accordance to Langmuir and Freundlich modelling (Figure 6). While, the calculated parameters of both isotherms and the estimated $\mathrm{R}^{2} \& \mathrm{x}^{2}$ were all presented in Table 2. According to the values of $x^{2}$ and $\mathrm{R}^{2}$, the adsorptive removal of carbofuran was well fitted to Langmuir isotherm rather than Freundlich modelling. Langmuir isotherm clarified that the adsorption of carbofuran onto the applied films performed through monolayer formation [47]. The calculated maximum capacities $\left(Q_{\max }, \mathrm{mg} / \mathrm{g}\right)$ for carbofuran adsorptive removal were greatly enlarged from $160.8 \mathrm{mg} / \mathrm{g}$ for PAN to $292.2 \mathrm{mg} / \mathrm{g}$ for P-PAN and to $489.5-690.1 \mathrm{mg} / \mathrm{g}$ for $\mathrm{NH}_{2}-\mathrm{MIL}-\mathrm{Ti} @ P-P A N$, respectively. The maximum carbofuran adsorption capacity of P-PAN film was enhanced by 1.7 and 2.4 times at incorporation of $10 \%$ and $30 \% \mathrm{NH}_{2}-\mathrm{MIL}-\mathrm{Ti}$, respectively. The obtained findings approved the superiority of $30 \% \mathrm{NH}_{2}-\mathrm{MIL}-\mathrm{Ti} @ P-P A N$ film in the removal of carbofuran.

Adsorptive removal of carbofuran onto the applied films can be described by physical and chemical adsorption. The physical adsorptive removal might be carried out by the pores of P-PAN film and pores of $\mathrm{NH}_{2}-\mathrm{MIL}-\mathrm{Ti}$ as a kind of coordination polymer which characterized by its porous framework. The higher adsorption capacity of P-PAN than that of PAN confirmed this hypothesis. For chemical adsorption, the reactive groups of films ( $\mathrm{CN}$ of P-PAN and $\mathrm{COO} \& \mathrm{Ti}$ in $\mathrm{CP}$ ) could be chemically interacted with the functional groups of carbofuran $(\mathrm{N}, \mathrm{O})$ as suggested in Figure 7. Coordinating bonds formed between $\mathrm{Ti}$ in film and $\mathrm{N} \& \mathrm{O}$ in carbofuran, while, $\mathrm{N}$ of $\mathrm{CN}$ and $\mathrm{O}$ of $\mathrm{COO}$ in the film interacted by $\mathrm{H}$ - bonds with $\mathrm{H}$ of $\mathrm{N}$ in carbofuran $[26,37,38]$. Furthermore, the aromatic ring of 2-aminoterphethalic acid can compose $\pi-$ $\pi$ interactions with the benzene ring of carbofuran $[26,48,49]$. Due to the several functional groups as reactive sites, $\mathrm{NH}_{2}$-MIL-Ti@P-PAN film exhibited extremely greater adsorptive removal of carbofuran comparing to P-PAN film. This postulation further emphasized by the observable increment in the adsorptive removal capacity of carbofuran with increasing the immobilized content of $\mathrm{NH}_{2}-\mathrm{MIL}-\mathrm{Ti}$ from $10-30 \%$ in the film. In accordance to Langmuir isotherm, monolayer adsorption was implemented by a limit of adsorption in the active sites of film including pores and the accessible functional groups [50]. Consequently, each active site in the applied film was full by only one carbofuran molecule resulting of one layer. The pseudo 2 nd ordered model declared that the carbofuran adsorption onto the applied film was relied on the contents of the active sites (pores and functional groups) and the concentration of carbofuran [47]. Subsequently, the adsorptive removal capacity of carbofuran could be further improved by immobilization much higher $\mathrm{NH}_{2}-\mathrm{MIL}-\mathrm{Ti}$ content within the film.

In order to highlight the superiority of the currently prepared $\mathrm{NH}_{2}-\mathrm{MIL}-\mathrm{Ti} @ P-P A N$ film in the adsorptive removal of carbofuran $(690.1 \mathrm{mg} / \mathrm{g})$, comparative overview for series of adsorbents in literature was presented in Table 3. Many of the summarized adsorbent materials (indian soils, slow pyrolyzed 
sugarcane bagasse biochar, animal bone meal, tea waste biochars, magnetic peanut shell, granular activated carbon, commercial activated carbon) showed very low adsorption capacity for carbofuran (0.9 - $97.1 \mathrm{mg} / \mathrm{g}$ ) [22-28]. Much high carbofuran adsorption was obtained $(137.0-312.5 \mathrm{mg} / \mathrm{g})$ at using date seed activated carbon, modified maize cobs waste, steam-activated biochar, palm oil fronds activated carbon, magnetic sugarcane bagasse, mesoporous activated carbon, steel industry wastes, activated carbon from rice straw and rice straw-derived activated carbon [28, 51-58]. However, the presently synthesized 30\% $\mathrm{NH}_{2}-\mathrm{MIL}$-Ti@P-PAN film exhibited extremely greater carbofuran adsorption than that of all the adsorbents reported in Table 3 by factor of more than 2. Additionally, $\mathrm{NH}_{2}-\mathrm{MIL}-\mathrm{Ti} @ \mathrm{P}-$ PAN film was advantageously characterized by the recyclability efficiency. Therefore, the currently obtained $\mathrm{NH}_{2}$-MIL-Ti@P-PAN film is an excellent adsorptive film for removal of carbofuran with higher applicability and hence it could be more desirable for removal of different insecticides. 
Table 3

Adsorption capacity for carbofuran onto different adsorbents reported in literature.

\begin{tabular}{|c|c|c|c|}
\hline Adsorbent & $\begin{array}{l}Q_{\max } \\
(\mathrm{mg} / \mathrm{g})\end{array}$ & Reference & Reference \\
\hline $30 \% \mathrm{NH}_{2}-\mathrm{MIL}-\mathrm{Ti} @ \mathrm{P}-\mathrm{PAN}$ & 690.1 & $\begin{array}{l}\text { Current } \\
\text { work }\end{array}$ & Current work \\
\hline Indian soils & $0.9-4.9$ & 18 & $\begin{array}{l}\text { Krishna, K. R., \& Philip, L., } \\
2008\end{array}$ \\
\hline $\begin{array}{l}\text { Slow pyrolyzed sugarcane bagasse } \\
\text { biochar }\end{array}$ & $3.6-18.9$ & 21 & Vimal, V., et al., 2019 \\
\hline Animal bone meal & 18.5 & 20 & Roudani, A., et al., 2014 \\
\hline Tea waste biochars & $22.8-54.7$ & 22 & Mayakaduwa, S., et al, 2016 \\
\hline Magnetic peanut shell & 89.3 & 23 & $\begin{array}{l}\text { Toledo-Jaldin, H. P., et al., } \\
2020\end{array}$ \\
\hline Granular activated carbon & 96.2 & 17 & $\begin{array}{l}\text { Salman, J., \& Hameed, B., } \\
2010\end{array}$ \\
\hline Commercial activated carbon & 97.1 & 19 & Salman, J., et al., 2011a \\
\hline Date seed activated carbon & 137.0 & 52 & Salman, J., et al., 2011b \\
\hline Modified maize cobs waste & 149.2 & 51 & Foo, K., 2016 \\
\hline Steam-activated biochar & 160.8 & 56 & $\begin{array}{l}\text { Mayakaduwa, S., et al., } \\
2017\end{array}$ \\
\hline Palm-oil-fronds-activated carbon & 164.0 & 54 & Salman, J. M., 2013 \\
\hline Magnetic sugarcane bagasse & 175.0 & 23 & $\begin{array}{l}\text { Toledo-Jaldin, H. P., et al., } \\
2020\end{array}$ \\
\hline Mesoporous activated carbon & $\begin{array}{l}193.1- \\
205.0\end{array}$ & 50 & Njoku, V., et al., 2014 \\
\hline Steel industry wastes & 208.0 & 49 & Gupta, V. K., et al., 2006 \\
\hline Activated carbon from rice straw & 296.5 & 55 & Chang, K.-L., et al., 2011 \\
\hline Rice straw-derived activated carbon & $\begin{array}{l}222.2- \\
312.5\end{array}$ & 53 & Chang, K.-L., et al., 2014 \\
\hline
\end{tabular}

\section{Recoverability}

The four synthesized films (PAN, P-PAN, 10\% $\mathrm{NH}_{2}$-MIL-Ti@P-PAN and 30\% $\mathrm{NH}_{2}$-MIL-Ti@P-PAN) were utilized in the study the recyclability for carbofuran adsorption up to six repetitive cycles. Figure 8 showed that carbofuran adsorption by the applied films was slightly reduced after reusing which is due to the 
leaching of some of $\mathrm{NH}_{2}$-MIL-Ti from the film during the adsorption/desorption process. For $30 \% \mathrm{NH}_{2}-$ MIL-Ti@P-PAN film, the adsorptive removal capacity was decreased from $360 \mathrm{mg} / \mathrm{g}$ to $315 \mathrm{mg} / \mathrm{g}$ after six reusing cycles which means that the adsorption of carbofuran was lowered by only $12.5 \%$ when re-using for six repetitive cycles. These could explain that the employed $\mathrm{NH}_{2}$-MIL-Ti@P-PAN film exhibited a superior recyclability in carbofuran removal that approved its wide exploitability in removing of insecticides. The synthesized $\mathrm{NH}_{2}$-MIL-Ti@P-PAN film might be promisingly employed in removal of toxic \& hazardous materials from water with highly applicability which support its application in environmental purposes.

\section{Conclusion}

Highly adsorptive porous film of $\mathrm{NH}_{2}-\mathrm{MIL}-\mathrm{Ti} @ P-P A N$ was successively synthesized by immobilization of $\mathrm{NH}_{2}-\mathrm{MIL}-\mathrm{Ti} \mathrm{CP}$ within the pre-prepared porous polyacrylonitrile film. The obtained films were investigated by SEM, XRD and FTIR. The estimated pore diameter of PAN film was $8.5-51.2 \mu \mathrm{m}$. The adsorption of carbofuran insecticide onto the obtained films was systematically studied. The adsorption of carbofuran was fitted to Langmuir isotherm and pseudo 2 nd ordered model. The maximum adsorptive removal of carbofuran onto films was extensively enlarged from $160.8 \mathrm{mg} / \mathrm{g}$ for PAN to $292.2 \mathrm{mg} / \mathrm{g}$ for P-PAN and to $489.5-690.1 \mathrm{mg} / \mathrm{g}$ for $\mathrm{NH}_{2}$-MIL-Ti@P-PAN. The removal capacity of P-PAN film was improved by factor of 2.4 at immobilization of $30 \% \mathrm{NH}_{2}-\mathrm{MIL}-\mathrm{Ti}$, respectively. The applied $\mathrm{NH}_{2}-\mathrm{MIL}-\mathrm{Ti} @ P-P A N$ film exhibited quite good recyclability, and the carbofuran adsorptive removal capacity was lowered by only $12.5 \%$ after 6 repetitive applied cycles. Regarding to the conventional techniques for removal of carbofuran mentioned in literature, the prepared $\mathrm{NH}_{2}$-MIL-Ti@P-PAN film showed advantageous properties of high adsorptive removal efficiency, and recyclability. Thus, the exploited porous film could be described as successfully functionalized in removal of insecticides and hazardous materials and could be promisingly applicable in other environmental applications.

\section{Declarations}

\section{Compliance with ethical standards}

The authors declare that they have no conflict of interest

\section{Acknowledgement}

We extend our sincere appreciation to the Researchers Supporting Project number (RSP-2021/79) at King Saud University, Riyadh, Saudi Arabia.

\section{Conflict of Interest}

The authors declare no conflict of interest. 


\section{References}

1. G.R. Hallberg, Agricultural chemicals in ground water: Extent and implications. American journal of alternative agriculture 2(1), 3-15 (1987)

2. B.C. Kross, A. Vergara, L.E. Raue, Toxicity assessment of atrazine, alachlor, and carbofuran and their respective environmental metabolites using microtox. Journal of Toxicology and Environmental Health, Part A Current Issues 37(1), 149-159 (1992)

3. R. Bushway, H. Hurst, L. Perkins, L. Tian, C.G. Cabanillas, B. Young, B. Ferguson, H. Jennings, Atrazine, alachlor, and carbofuran contamination of well water in central maine. Bull. Environ Contam. Toxicol. 49(1), 1-9 (1992)

4. D. Waite, H. Sommerstad, R. Grover, L. Kerr, N. Westcott, Pesticides in ground water, surface water and spring runoff in a small saskatchewan watershed. Environmental Toxicology and Chemistry: An International Journal 11(6), 741-748 (1992)

5. R.A. Soomro, A. Nafady, S.T.H. Sherazi, N.H. Kalwar, M.R. Shah, K.R. Hallam, Catalytic reductive degradation of methyl orange using air resilient copper nanostructures. Journal of Nanomaterials 2015 (2015)

6. S.S. Hassan, S. Panhwar, A. Nafady, A.M. Al-Enizi, S.T.H. Sherazi, M.S. Kalhoro, M. Arain, M.R. Shah, M.Y. Talpur, Fabrication of highly sensitive and selective electrochemical sensors for detection of paracetamol by using piroxicam stabilized gold nanoparticles. Journal of The Electrochemical Society 164(9), B427 (2017)

7. G. Sharma, A. Kumar, S. Sharma, S.I. Al-Saeedi, G.M. Al-Senani, A. Nafady, T. Ahamad, M. Naushad, F.J. Stadler, Fabrication of oxidized graphite supported la2o3/zro2 nanocomposite for the photoremediation of toxic fast green dye. J. Mol. Liq. 277, 738-748 (2019)

8. T. Momić, T.L. Pašti, U. Bogdanović, V. Vodnik, A. Mraković, Z. Rakočević, V.B. Pavlović, V. Vasić, Adsorption of organophosphate pesticide dimethoate on gold nanospheres and nanorods. Journal of Nanomaterials 2016(2016)

9. L. Clausen, I. Fabricius, L. Madsen, Adsorption of pesticides onto quartz, calcite, kaolinite, and aalumina. J. Environ. Qual. 30(3), 846-857 (2001)

10. E. Ayranci, N. Hoda, Adsorption kinetics and isotherms of pesticides onto activated carbon-cloth. Chemosphere 60(11), 1600-1607 (2005)

11. S.M. Maliyekkal, T. Sreeprasad, D. Krishnan, S. Kouser, A.K. Mishra, U.V. Waghmare, T. Pradeep, Graphene: A reusable substrate for unprecedented adsorption of pesticides. Small 9(2), 273-283 (2013)

12. K. Simeonidis, S. Mourdikoudis, E. Kaprara, M. Mitrakas, L. Polavarapu, Inorganic engineered nanoparticles in drinking water treatment: A critical review. Environmental Science: Water Research \& Technology 2(1), 43-70 (2016)

13. M.M. Mirković, T.L. Pašti, A.M. Došen, M. Čebela, A. Rosić, B. Matović, B.M. Babić, Adsorption of malathion on mesoporous monetite obtained by mechanochemical treatment of brushite. Rsc 
Advances 6(15), 12219-12225 (2016)

14. P. Wang, Y. Yin, Y. Guo, C. Wang, Preponderant adsorption for chlorpyrifos over atrazine by wheat straw-derived biochar: Experimental and theoretical studies. RSC Adv. 6(13), 10615-10624 (2016)

15. T.D. Lazarević-Pašti, I.A. Pašti, B. Jokić, B.M. Babić, V.M. Vasić, Heteroatom-doped mesoporous carbons as efficient adsorbents for removal of dimethoate and omethoate from water. RSC Adv. 6(67), 62128-62139 (2016)

16. T. Lazarević-Pašti, V. Anićijević, M. Baljozović, D.V. Anićijević, S. Gutić, V. Vasić, N.V. Skorodumova, I.A. Pašti, The impact of the structure of graphene-based materials on the removal of organophosphorus pesticides from water. Environmental Science: Nano 5(6), 1482-1494 (2018)

17. K.M. Kabir, Y.M. Sabri, A.E. Kandjani, G.I. Matthews, M. Field, L.A. Jones, A. Nafady, S.J. Ippolito, S.K. Bhargava, Mercury sorption and desorption on gold: A comparative analysis of surface acoustic wave and quartz crystal microbalance-based sensors. Langmuir 31(30), 8519-8529 (2015)

18. A. Nafady, H. Afridi, S. Sara, A. Shah, A. Niaz, Direct synthesis and stabilization of bi-sized cysteinederived gold nanoparticles: Reduction catalyst for methylene blue. J. Iran. Chem. Soc. 8(1), S34-S43 (2011)

19. P.G. Moradeeya, M.A. Kumar, R.B. Thorat, M. Rathod, Y. Khambhaty, S. Basha, Nanocellulose for biosorption of chlorpyrifos from water: Chemometric optimization, kinetics and equilibrium. Cellulose 24(3), 1319-1332 (2017)

20. J. Yang, C. Ma, J. Tao, J. Li, K. Du, Z. Wei, C. Chen, Z. Wang, C. Zhao, M. Ma, Optimization of polyvinylamine-modified nanocellulose for chlorpyrifos adsorption by central composite design. Carbohyd. Polym. 245, 116542 (2020)

21. J.L. Milagres, C.R. Bellato, S.O. Ferreira, L. de Moura Guimarães, Preparation and evaluation of hydrocalumite-iron oxide magnetic intercalated with dodecyl sulfate for removal of agrichemicals. Journal of environmental management 255(109845(2020)

22. J. Salman, B. Hameed, Adsorption of 2, 4-dichlorophenoxyacetic acid and carbofuran pesticides onto granular activated carbon. Desalination 256(1-3), 129-135 (2010)

23. K.R. Krishna, L. Philip, Adsorption and desorption characteristics of lindane, carbofuran and methyl parathion on various indian soils. J. Hazard. Mater. 160(2-3), 559-567 (2008)

24. J. Salman, F. Abd, A. Muhammed, Adsorption of carbofuran insecticide from aqueous solution using commercial activated carbon. Int. J. Chem. Sci. 9(2), 557-564 (2011)

25. A. Roudani, R. Mamouni, N. Saffaj, A. Laknifli, S. Gharby, A. Faouzi: Removal of carbofuran pesticide from aqueous solution by adsorption onto animal bone meal as new low cost adsorbent. Chemical and Process Engineering Research 28(2014) (2014)

26. V. Vimal, M. Patel, D. Mohan, Aqueous carbofuran removal using slow pyrolyzed sugarcane bagasse biochar: Equilibrium and fixed-bed studies. RSC Adv. 9(45), 26338-26350 (2019)

27. S. Mayakaduwa, M. Vithanage, A. Karunarathna, D. Mohan, Y.S. Ok, Interface interactions between insecticide carbofuran and tea waste biochars produced at different pyrolysis temperatures. Chemical Speciation \& Bioavailability 28(1-4), 110-118 (2016) 
28. H.P. Toledo-Jaldin, V. Sánchez-Mendieta, A. Blanco-Flores, G. López-Téllez, A.R. Vilchis-Nestor, O. Martín-Hernández, Low-cost sugarcane bagasse and peanut shell magnetic-composites applied in the removal of carbofuran and iprodione pesticides. Environ. Sci. Pollut. Res. 27(8), 7872-7885 (2020)

29. G. Liu, L. Li, D. Xu, X. Huang, X. Xu, S. Zheng, Y. Zhang, H. Lin, Metal-organic framework preparation using magnetic graphene oxide- $\beta$-cyclodextrin for neonicotinoid pesticide adsorption and removal. Carbohydrate polymers $175,584-591$ (2017)

30. Y. Wang, W. Zhao, Z. Qi, L. Zhang, Y. Zhang, H. Huang, Y. Peng, Designing zif-8/hydroxylated mwcnt nanocomposites for phosphate adsorption from water: Capability and mechanism. Chemical Engineering Journal 124992(2020)

31. G. Wu, J. Ma, S. Li, S. Wang, B. Jiang, S. Luo, J. Li, X. Wang, Y. Guan, L. Chen, Cationic metal-organic frameworks as an efficient adsorbent for the removal of 2, 4-dichlorophenoxyacetic acid from aqueous solutions. Environmental Research 109542(2020)

32. R.M. Abdelhameed, M. Taha, H. Abdel-Gawad, F. Mahdy, B. Hegazi, Zeolitic imidazolate frameworks: Experimental and molecular simulation studies for efficient capture of pesticides from wastewater. Journal of Environmental Chemical Engineering 7(6), 103499 (2019)

33. Q. Yang, J. Wang, W. Zhang, F. Liu, X. Yue, Y. Liu, M. Yang, Z. Li, J. Wang, Interface engineering of metal organic framework on graphene oxide with enhanced adsorption capacity for organophosphorus pesticide. Chem. Eng. J. 313, 19-26 (2017)

34. R.M. Abdelhameed, M. Taha, H. Abdel-Gawad, B. Hegazi, Amino-functionalized al-mil-53 for dimethoate pesticide removal from wastewater and their intermolecular interactions. Journal of Molecular Liquids114852 (2020)

35. V. Romero, S.P. Fernandes, P. Kováŕ, M. Pšenička, Y.V. Kolen'ko, L.M. Salonen, B. Espiña, Efficient adsorption of endocrine-disrupting pesticides from water with a reusable magnetic covalent organic framework. Microporous and Mesoporous Materials 307(110523(2020)

36. H.E. Emam, H.B. Ahmed, E. Gomaa, M.H. Helal, R.M. Abdelhameed, Doping of silver vanadate and silver tungstate nanoparticles for enhancement the photocatalytic activity of mil-125-nh2 in dye degradation. J. Photochem. Photobiol., A 383, 111986 (2019)

37. H.E. Emam, H.B. Ahmed, E. Gomaa, M.H. Helal, R.M. Abdelhameed, Recyclable photocatalyst composites based on ag 3 vo 4 and ag 2 wo 4@mof@ cotton for effective discoloration of dye in visible light. Cellulose 1-17(2020)

38. R.M. Abdelhameed, M. El-Shahat, H.E. Emam, Employable metal (ag \& pd)@ mil-125-nh2@ cellulose acetate film for visible-light driven photocatalysis for reduction of nitro-aromatics. Carbohyd. Polym. 247, 116695 (2020)

39. H. Zhang, L. Xu, F. Yang, L. Geng, The synthesis of polyacrylonitrile/carbon nanotube microspheres by aqueous deposition polymerization under ultrasonication. Carbon 48(3), 688-695 (2010)

40. Y. Furushima, M. Nakada, H. Takahashi, K. Ishikiriyama, Study of melting and crystallization behavior of polyacrylonitrile using ultrafast differential scanning calorimetry. Polymer 55(13), 3075-3081 
(2014)

41. C. Li, Z. Xiong, J. Zhang, C. Wu, The strengthening role of the amino group in metal-organic framework mil-53 (al) for methylene blue and malachite green dye adsorption. Journal of Chemical \& Engineering Data 60(11), 3414-3422 (2015)

42. X. Cheng, A. Zhang, K. Hou, M. Liu, Y. Wang, C. Song, G. Zhang, X. Guo, Size-and morphologycontrolled nh 2-mil-53 (al) prepared in dmf-water mixed solvents. Dalton Trans. 42(37), 1369813705 (2013)

43. A. Jenab, R. Roghanian, N. Ghorbani, K. Ghaedi, G. Emtiazi, The efficacy of electrospun pan/kefiran nanofiber and kefir in mammalian cell culture: Promotion of pc12 cell growth, anti-mcf7 breast cancer cells activities, and cytokine production of pbmc. International journal of nanomedicine 15(717(2020)

44. R. Ojeda-López, J.M. Esparza-Schulz, I.J. Pérez-Hermosillo, A. Hernández-Gordillo, A. DomínguezOrtiz, Improve in $\mathrm{co} 2$ and ch4 adsorption capacity on carbon microfibers synthesized by electrospinning of pan. Fibers 7(10), 81 (2019)

45. S.M. Vilela, P. Salcedo-Abraira, I. Colinet, F. Salles, M.C. De Koning, M.J. Joosen, C. Serre, P. Horcajada, Nanometric mil-125-nh2 metal-organic framework as a potential nerve agent antidote carrier. Nanomaterials 7(10), ,321 (2017)

46. H.E. Emam, H.B. Ahmed, H.R. El-Deib, F.M. El-Dars, R.M. Abdelhameed, Non-invasive route for desulfurization of fuel using infrared-assisted mil-53 (al)-nh2 containing fabric. J. Colloid Interface Sci. 556, 193-205 (2019)

47. H.E. Emam, F.H. Abdellatif, R.M. Abdelhameed, Cationization of celluloisc fibers in respect of liquid fuel purification. J. Clean. Prod. 178, 457-467 (2018)

48. Y. Gao, K. Liu, R. Kang, J. Xia, G. Yu, S. Deng, A comparative study of rigid and flexible mofs for the adsorption of pharmaceuticals: Kinetics, isotherms and mechanisms. J. Hazard. Mater. 359, 248257 (2018)

49. R. Yu, Z. Wu, High adsorption for ofloxacin and reusability by the use of zif-8 for wastewater treatment. Microporous Mesoporous Mater. 308, 110494 (2020)

50. R.M. Abdelhameed, H.E. Emam, Design of zif (co \& zn)@ wool composite for efficient removal of pharmaceutical intermediate from wastewater. J. Colloid Interface Sci. 552, 494- 505 (2019)

51. V.K. Gupta, I. Ali, V.K. Saini, Adsorption of 2, 4-d and carbofuran pesticides using fertilizer and steel industry wastes. J. Colloid Interface Sci. 299(2), 556-563 (2006)

52. V. Njoku, M.A. Islam, M. Asif, B. Hameed, Preparation of mesoporous activated carbon from coconut frond for the adsorption of carbofuran insecticide. J. Anal. Appl. Pyrol. 110, 172-180 (2014)

53. K. Foo, Value-added utilization of maize cobs waste as an environmental friendly solution for the innovative treatment of carbofuran. Process Saf. Environ. Prot. 100, 295-304 (2016)

54. J. Salman, V. Njoku, B. Hameed, Bentazon and carbofuran adsorption onto date seed activated carbon: Kinetics and equilibrium. Chemical engineering journal 173(2), 361-368 (2011) 
55. K.-L. Chang, C.-C. Chen, J.-H. Lin, J.-F. Hsien, Y. Wang, F. Zhao, Y.-H. Shih, Z. Xing, S.-T. Chen, Rice straw-derived activated carbons for the removal of carbofuran from an aqueous solution. New Carbon Mater. 29(1), 47-54 (2014)

56. J.M. Salman, Batch study for insecticide carbofuran adsorption onto palm-oil-fronds-activated carbon. Journal of Chemistry 2013((2013)

57. K.-L. Chang, J.-H. Lin, S.-T. Chen, Adsorption studies on the removal of pesticides (carbofuran) using activated carbon from rice straw agricultural waste. World Academy of Science, Engineering and Technology 76, 348-351 (2011)

58. S. Mayakaduwa, I. Herath, Y.S. Ok, D. Mohan, M. Vithanage, Insights into aqueous carbofuran removal by modified and non-modified rice husk biochars. Environ. Sci. Pollut. Res. 24(29), 2275522763 (2017)

\section{Figures}

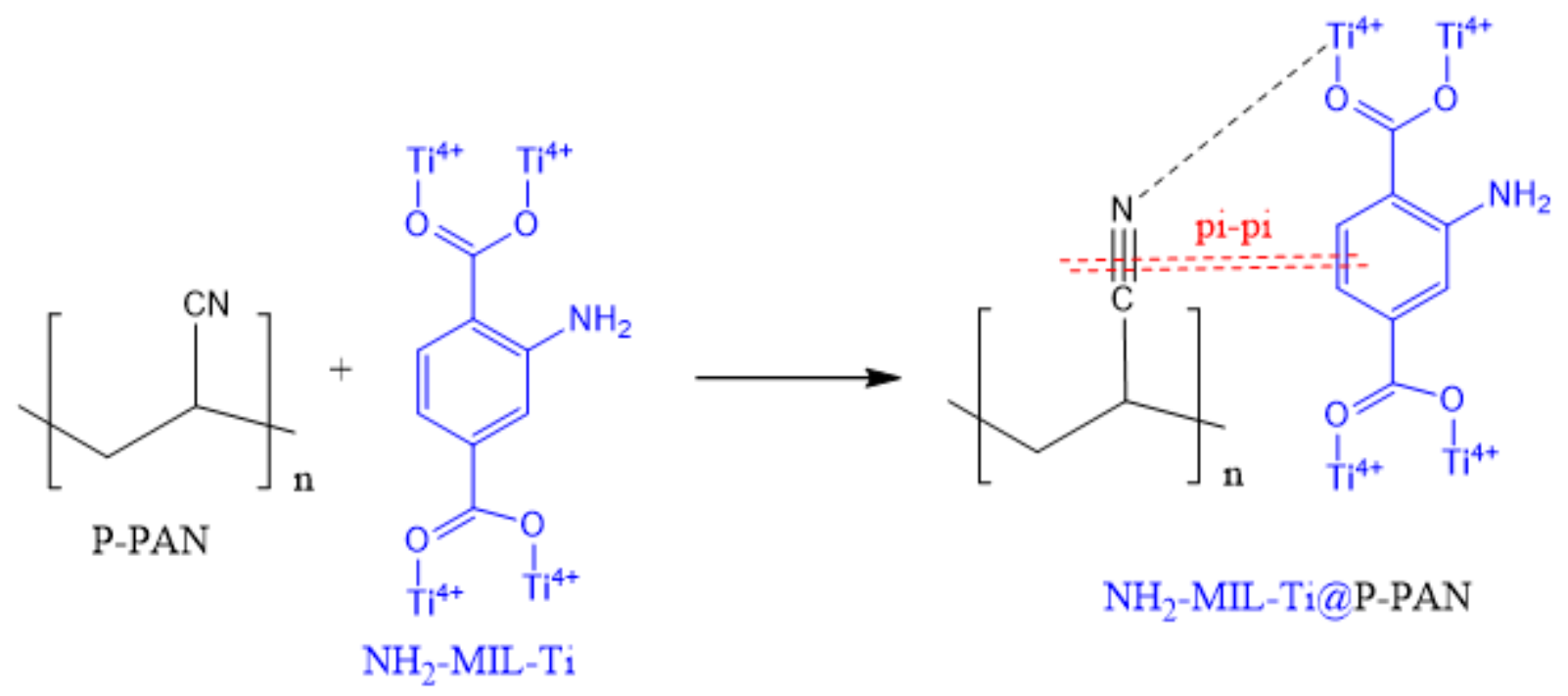

\section{Figure 1}

Preparation scheme of NH2-MIL-Ti@P-PAN film. 

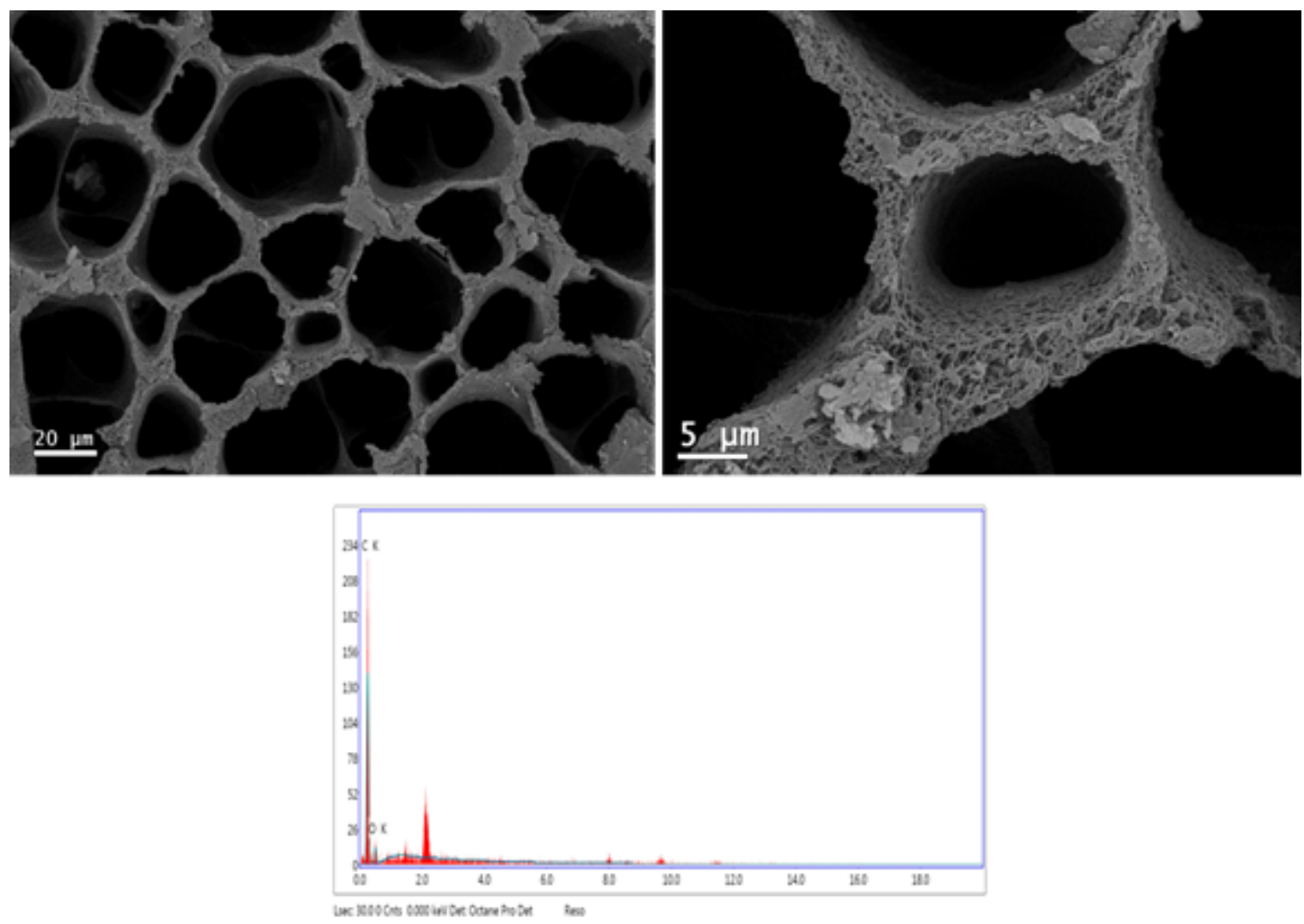

Figure 2

Scanning micrographs for the synthesized films; [a] P-PAN, [b] 10\% NH2-MIL-Ti@P-PAN and [c] 30\% NH2MIL-Ti@P-PAN. EDX analysis are presented below the micrographs

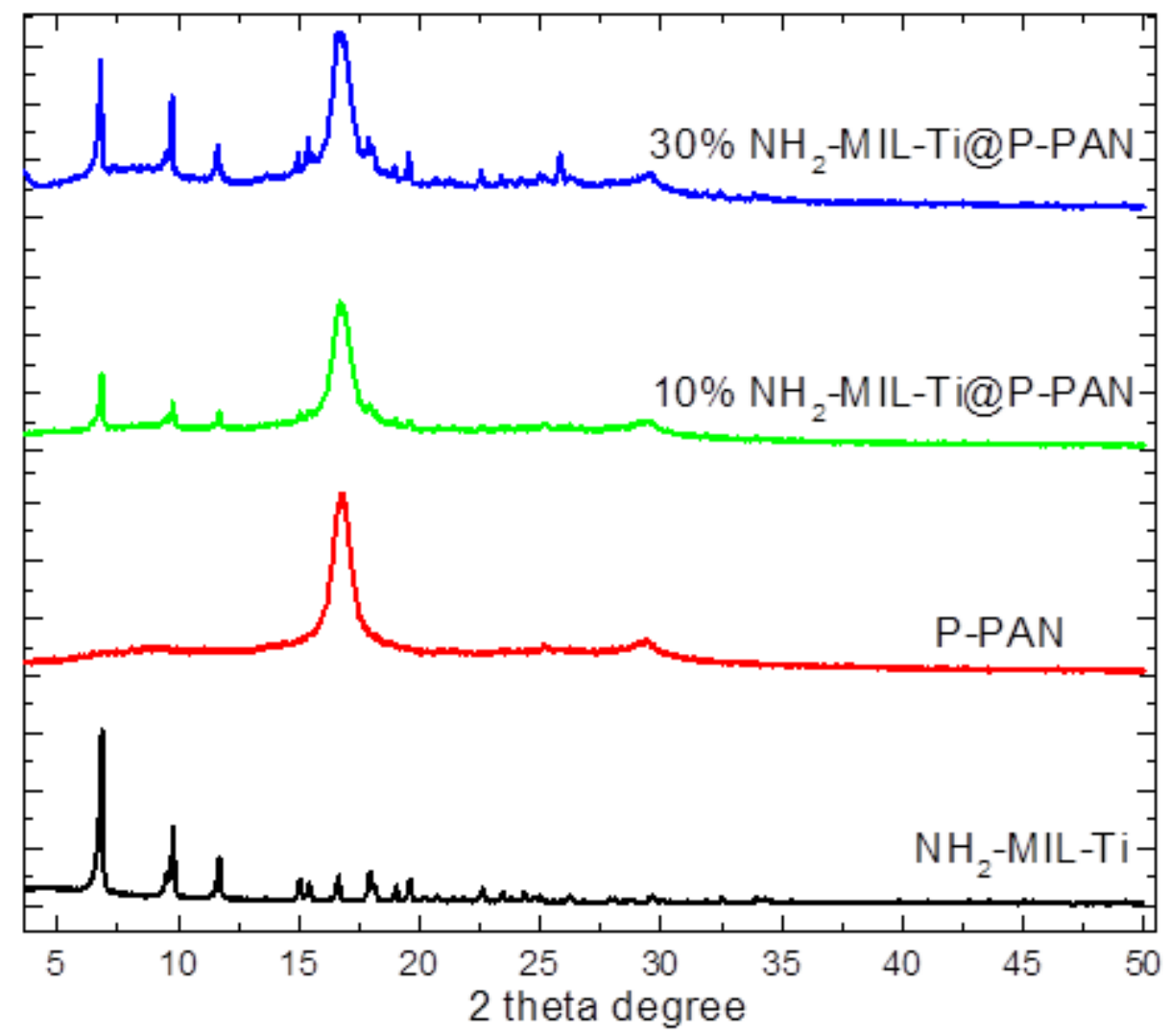


Figure 3

X-ray diffraction of the synthesized films.

a

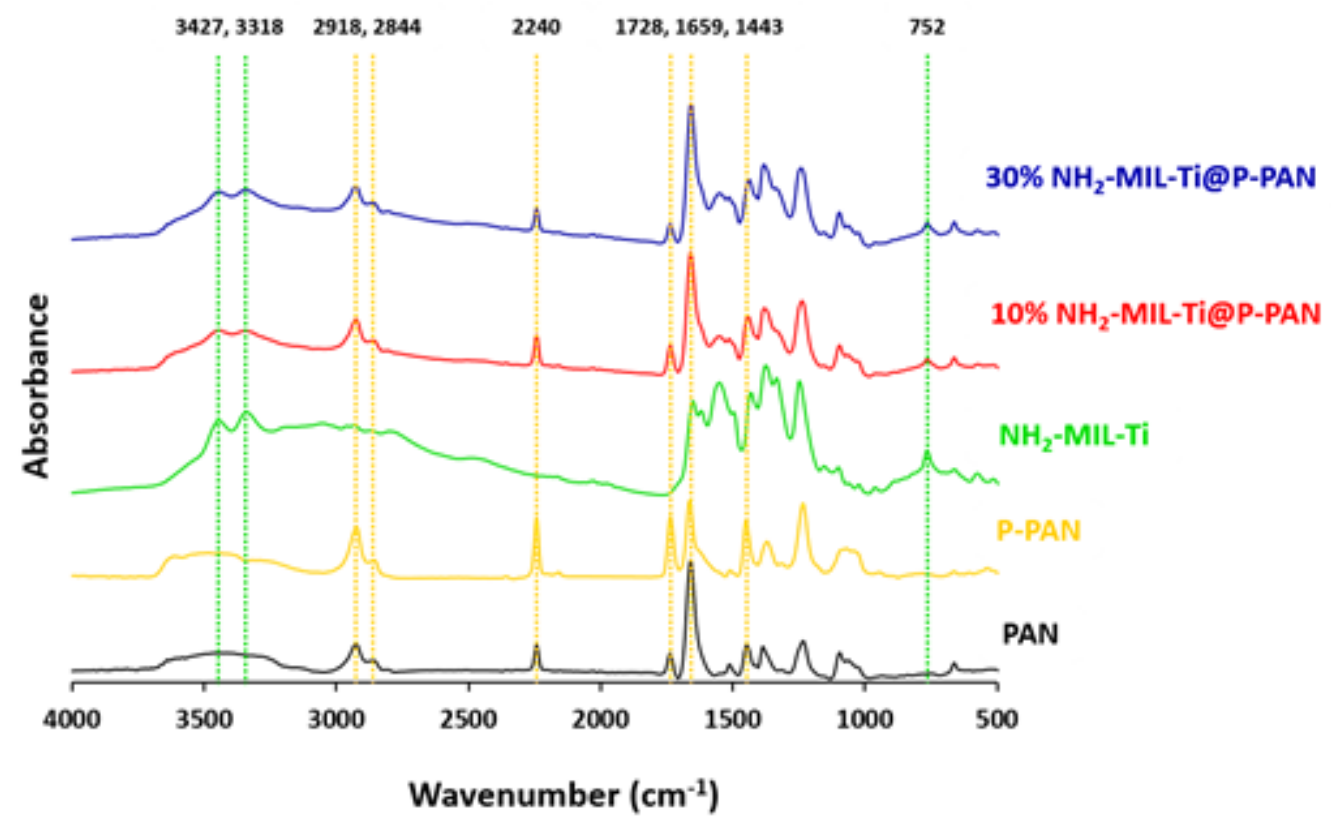

b

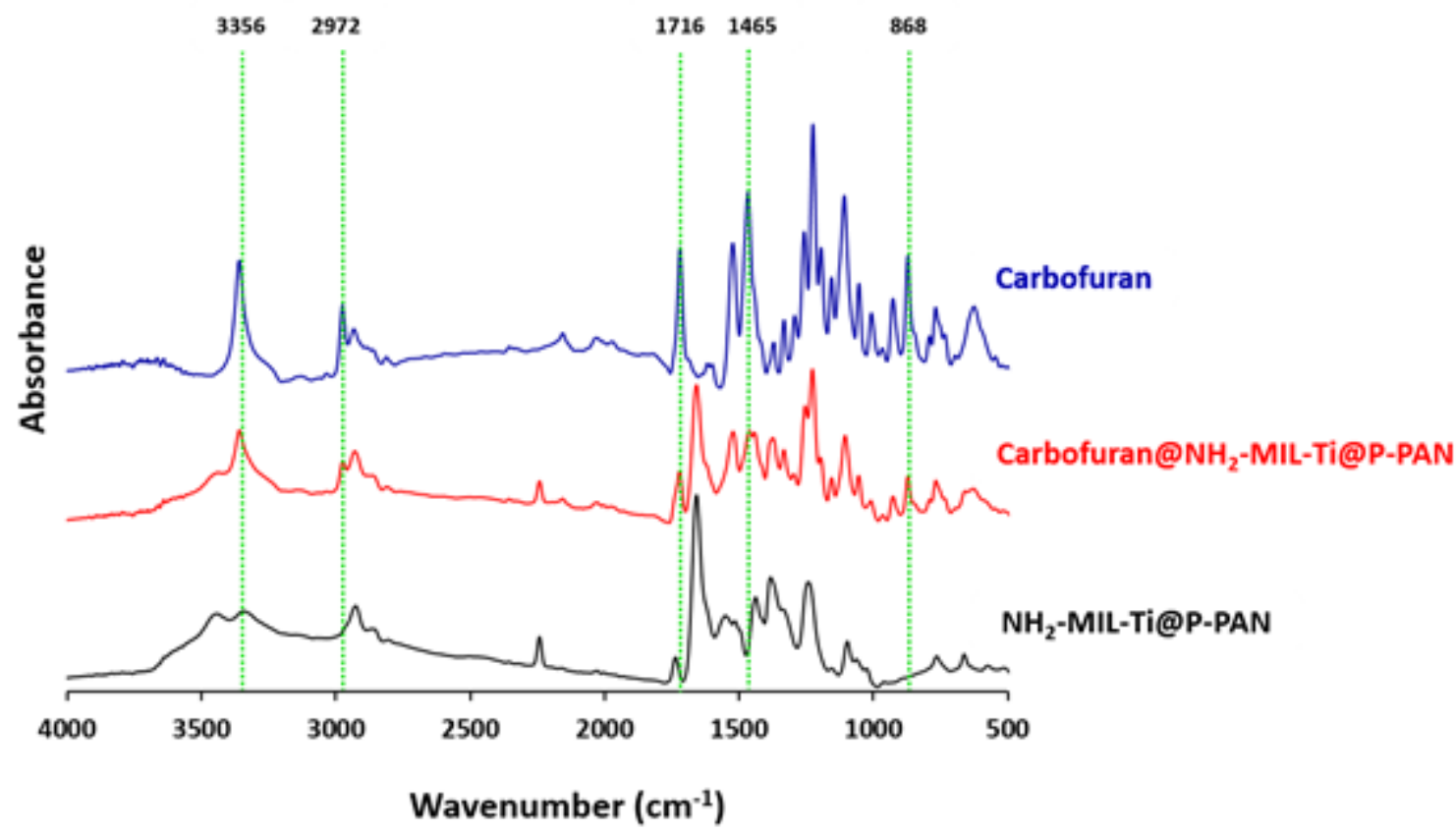

Figure 4

FTIR spectra for; [a] the synthesized films and [b] film after carbofuran adsorption. 
[a]

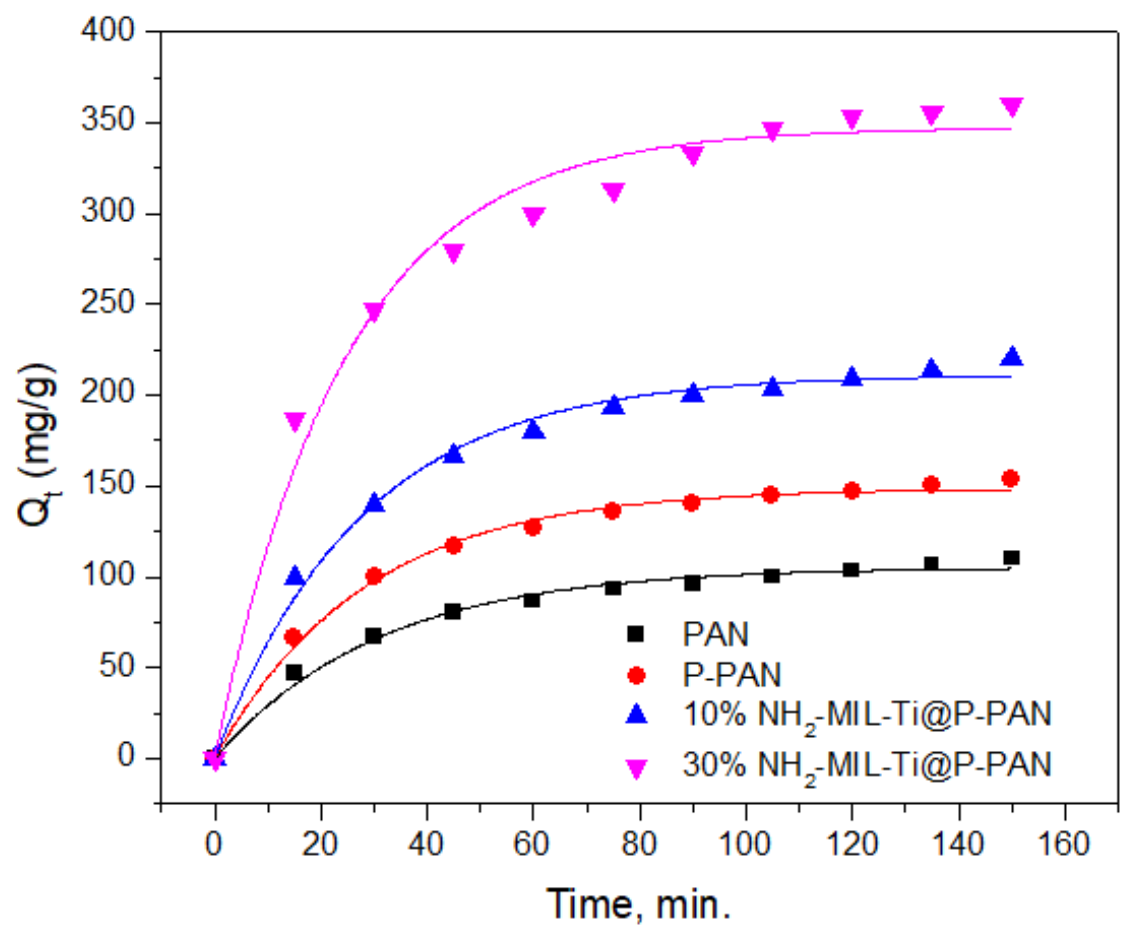

[b]

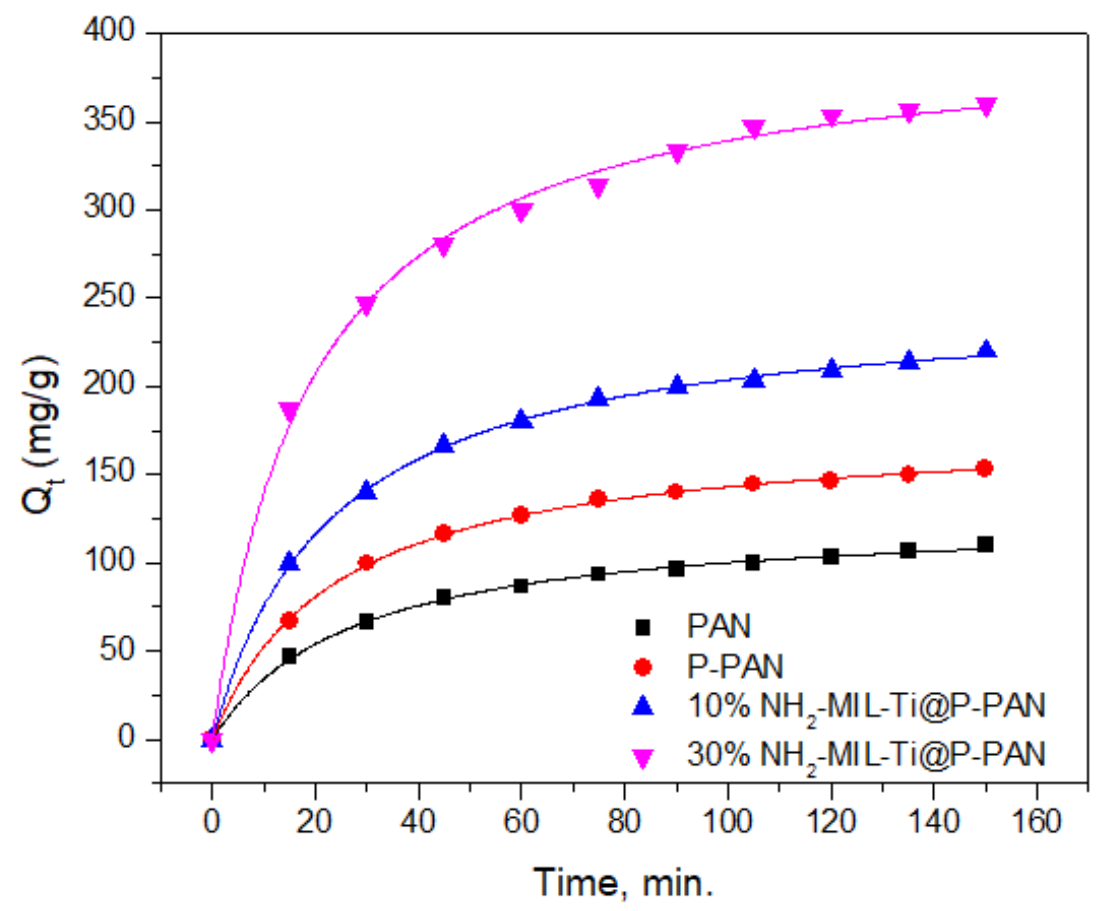

Figure 5

Adsorption kinetic of Carbofuran insecticide onto the synthesized films (PAN, P-PAN, 10\% NH2-MIL-Ti@PPAN and 30\% NH2-MIL-Ti@P-PAN); [a] pseudo-first order and [b] pseudo-second order. 
[a]

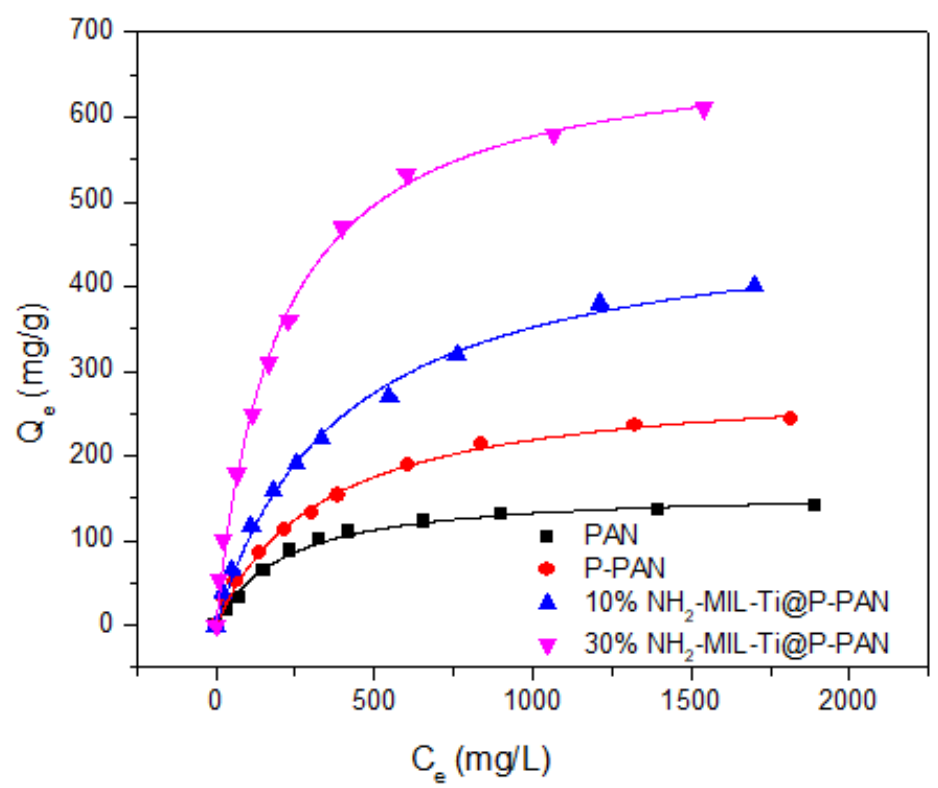

[b]

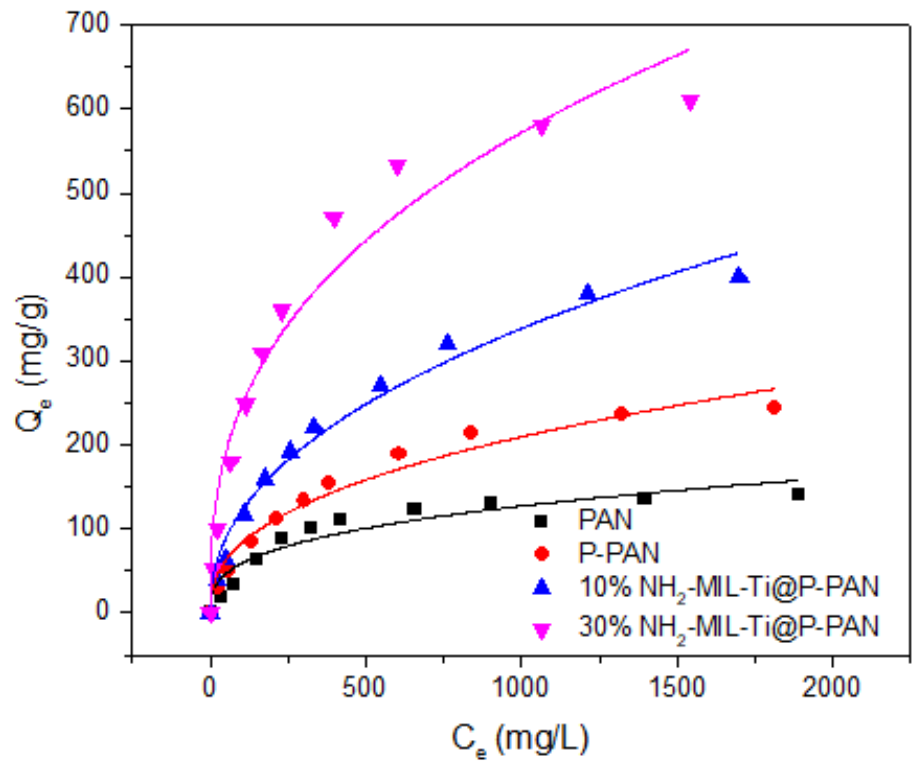

Figure 6

Adsorption isotherm of Carbofuran insecticide onto the synthesized films (PAN, P-PAN, 10\% NH2-MILTi@P-PAN and 30\% NH2-MIL-Ti@P-PAN); [a] Langmuir model and [b] Freundlich model. 


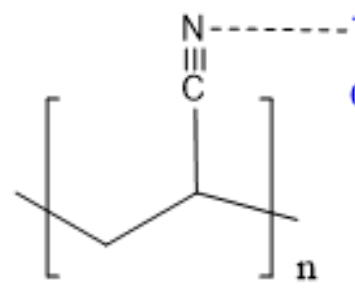

$\begin{array}{cc}-\mathrm{Ti}^{4+} & \mathrm{Ti}^{4+} \\ \mathrm{I}^{4+} & I^{0} \\ 0 & \mathrm{O}\end{array}$<smiles>Nc1ccccc1C(=O)O</smiles>

$\mathrm{NH}_{2}$-MIL-Ti@P-PAN

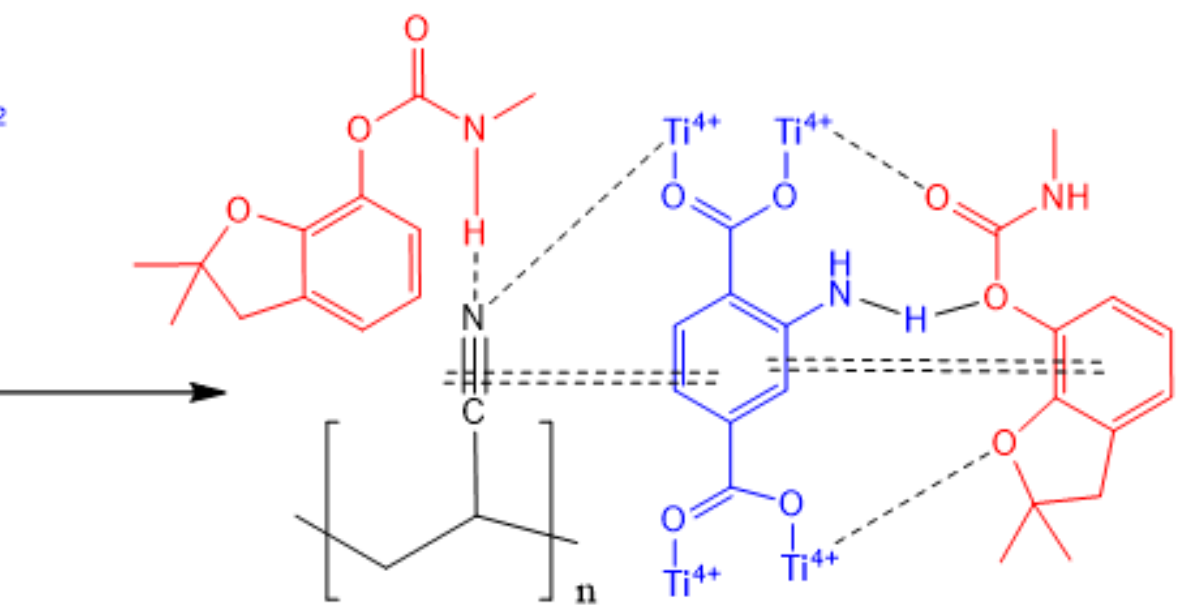<smiles>CNC(=O)Oc1cccc2c1OC(C)(C)C2</smiles>

Carbofuran@NH2-MIL-Ti@P-PAN

Carbofuran

Figure 7

The suggested adsorption scheme of Carbofuran insecticide onto NH2-MIL-Ti@P-PAN film.

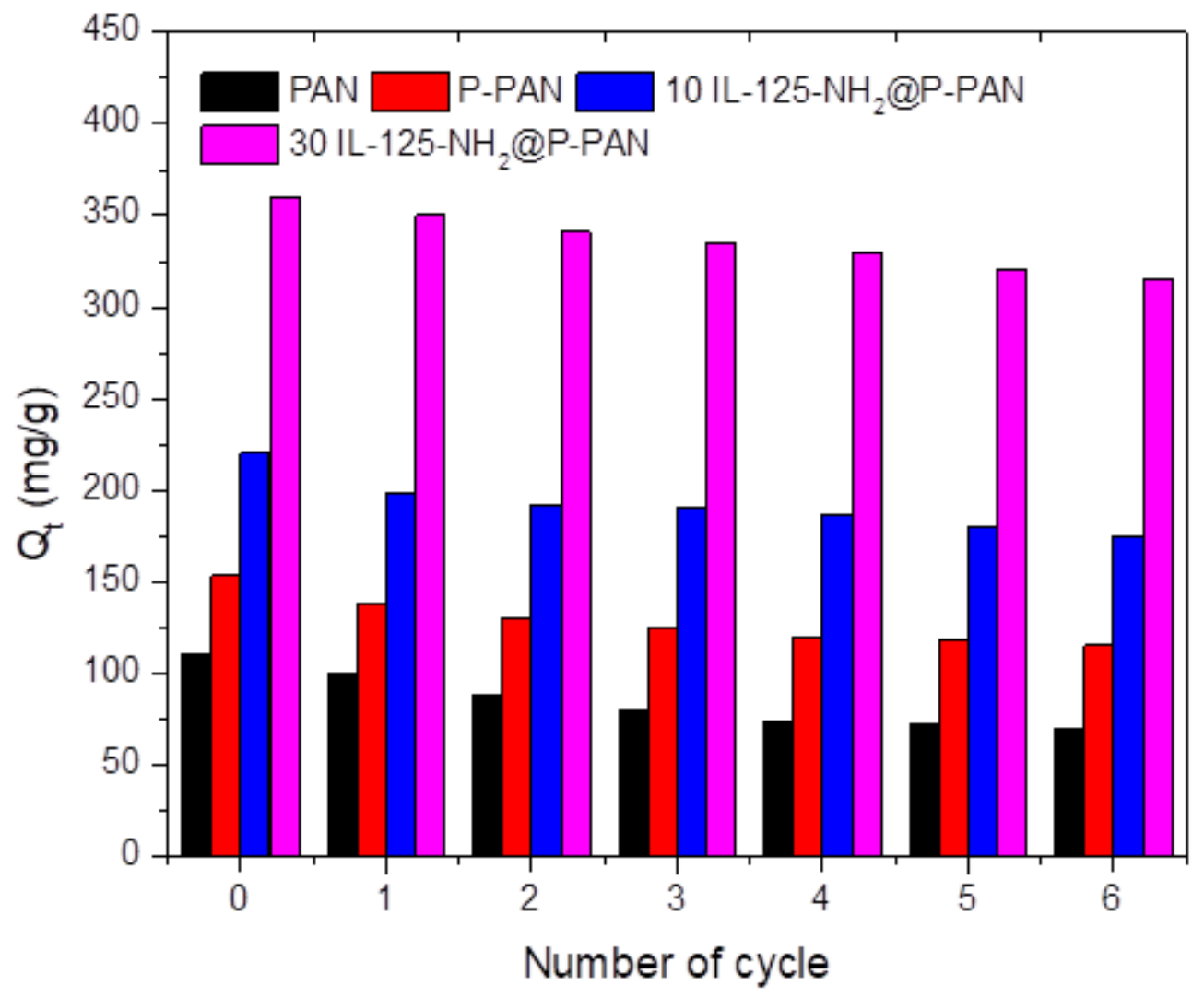


Figure 8

The effect of repetitive washings on the efficiency of NH2-MIL-Ti@P-PAN film in the adsorption of Carbofuran. 